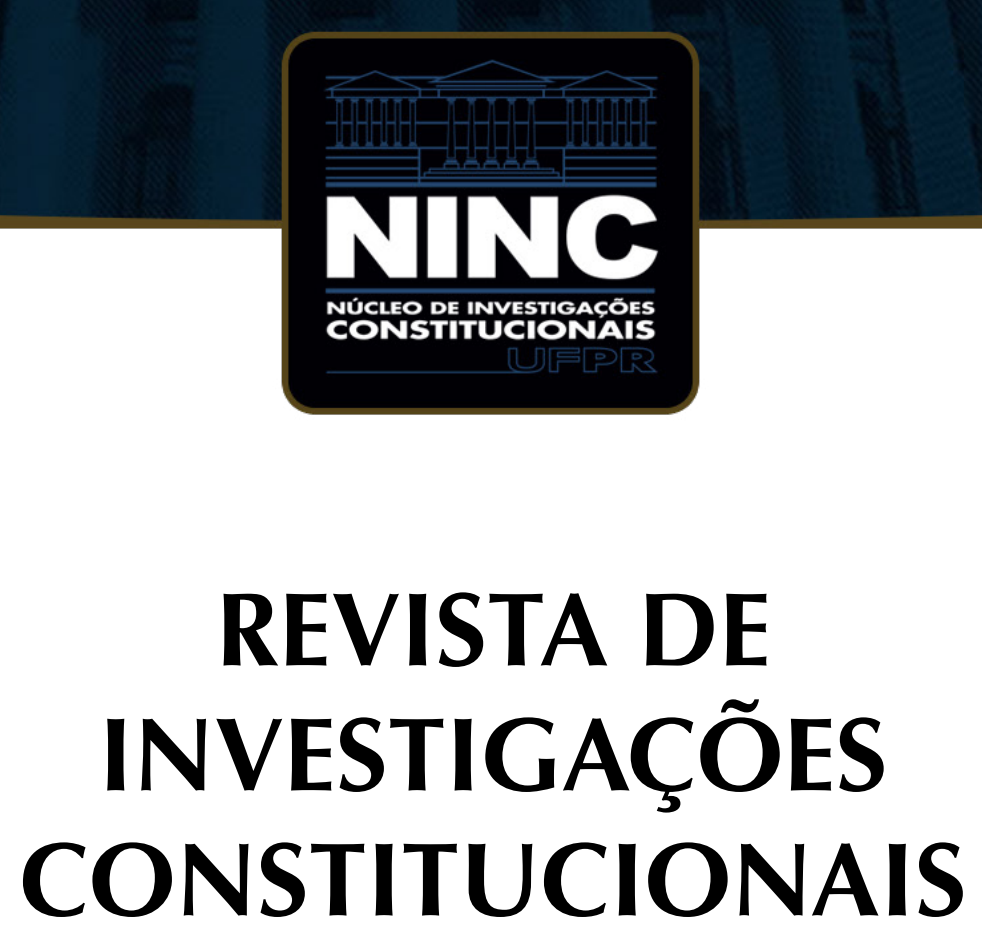

vol. 4 | n. 1 | janeiro/abril 2017 | ISSN 2359-5639 | Periodicidade quadrimestral Curitiba | Núcleo de Investigações Constitucionais da UFPR | www.ninc.com.br 


\section{Abortion Once Again: a response to Feser, Goodwin, Mosquito, Sadowsky, Vance and Watkins}

\section{Novamente o aborto: uma resposta a Feser, Goodwin, Mosquito, Sadowsky Vance e Watkins}

WALTER E. BLOCK*

Loyola University (United States of America) wblock@loyno.edu

Recebido/Received: 25.01.2017 / January 25th, 2017 Aprovado/Approved: 06.02.2017 / February 6th, 2017

\section{Abstract}

Only a libertarian would think to base an analysis of the abortion controversy on private property rights. The present paper does just that. On that basis, it concludes that evictionism is the only policy compatible with libertarianism. This essay then uses this analysis to criticize the views on this subject of five scholars associated with this political philosophy: Feser, Goodwin, Mosquito, Sadowsky, Vance and Watkins.

Keywords: pro-life; pro-choice; evictionism; libertarianism; abortion.

\section{Resumo}

Apenas um libertário pensaria em basear uma análise sobre a controvérsia do aborto em direitos de propriedade. $O$ presente artigo faz justamente isso. Seguindo essa linha, conclui-se que o eviccionismo é a única política compatível com o libertarianismo. Esse trabalho, pois, utiliza essa ferramenta de análise para criticar as opiniões sobre aborto de cinco professores alinhados a essa corrente filosófica: Feser, Goodwin, Mosquito, Sadowsky, Vance e Watkins.

Palavras-chave: pró-vida; pró-escolha; eviccionismo; libertarianismo; aborto.

Como citar esse artigo/How to cite this article: BLOCK, Walter E. Abortion Once Again: a response to Feser, Goodwin, Mosquito, Sadowsky, Vance and Watkins. Revista de Investigações Constitucionais, Curitiba, vol. 4, n. 1, p. 11-41, jan./abr. 2017. DOI: 10.5380/ rinc.v4i1.50328.

* Harold E. Wirth Eminent Scholar Endowed Chair in Economics at Loyola University College of Business (Chicago, United States of America). Ph.D. in Economics at Columbia University (New York, USA). B.A. in Philosophy, Brooklyn College (New York, USA). E-mail: wblock@loyno.edu. 


\section{CONTENTS}

1. Introduction; 2. Feser; 3. Goodwin; 3.1. Abortion is killing, but is it murder?; 3.2. When does life begin?; 3.3. Abortion and failure to come to the aid; 3.4. The unborn child is trespassing; 3.5 . There is no contract; 3.6. The mother can change her mind; 3.7. Evictionism; 3.8. Rights of the unborn child; 3.9. Causation; 3.10. Reasonable reliance (on promises); 3.11. A unilateral contract; 3.12. Lease; 3.13. Covenant of quiet enjoyment; 4. Mosquito; 5. Sadowsky; 6. Vence; 7. Watkins; 8. Conclusion; 9. References.

\section{INTRODUCTION}

Libertarianism is predicated upon the sanctity of private property rights and the non-aggression principle (NAP).

There has been an exhaustive and fierce debate amongst non-libertarians regarding the pro-choice versus pro-life philosophies. However, since none of them start off with libertarian principles, let alone adhere, rigidly, to them throughout, the conclusions they reach are almost necessarily guaranteed to diverge, widely, from those reached by members of the libertarian school of thought. The present paper considers several contributions to this debate authored by libertarians. If no one else can be expected to observe the NAP based on private property rights, then, at least, they can be expected to do so. Hence, we suspect, there might be a consensus, at least in this small arena of scholarship, on this issue. If so, we will be sadly disappointed. It would appear that this issue is fraught with so many complexities, and subtleties that even those who, presumably, start out on the basis of shared principles, all too often diverge from one another.

In the following sections of this paper we criticize the views on abortion on the part of several scholars associated with the libertarian political philosophy. They are in section II, Feser; III, Goodwin; IV, Mosquito; V, Sadowsky; V, Vance; VI, Watkins. Section $\mathrm{VII}$ is our conclusion. I have chosen these authors and their views on abortion because, while all are associated with libertarianism, none have supported the evictionist view I maintain is a direct deduction from libertarian principles, non-aggression, and private property rights based upon homesteading virgin territory. That is to say, it is my contention that libertarians who do not embrace evictionism fail to carry out, fully, the logic of their own basic premises. If I cannot even convince libertarians that evictionism is the only just answer to the pro-life, pro-choice controversy, then I have little hope to do so with the population at large. The present paper, then, is dedicated to trying to grab up low hanging intellectual fruit who do not accept evictionism as the only valid answer to the abortion debate. 


\section{FESER}

Feser's connection with libertarianism is tenuous at best. ${ }^{1}$ For one thing, he is concerned with "moral" issues, in contrast to libertarians who focus on a narrow subset of ethics, namely, what comprises just law.2 For another, he embraces positive obligations, anathema for the libertarian. ${ }^{3}$ He posits that "Adam" is the legitimate owner of an entire small island, and, yet, is obligated to stand by and allow "Zelda" to trespass on his property, given that she needs to do so in order to remain alive. On this ground, whenever anyone is starving anywhere on the planet, Feser's analysis would imply that other people are obligated to come to their rescue. Whatever else it may be, this doctrine is hardly a libertarian one. 4

However, Feser 5 quite properly takes Thomson 6 to task as favoring the pro-abortion side of the debate, and, also, convincingly undermines her position. The latter author, it will be remembered, analogizes pregnancy along the lines of a famous violinist being hooked up to your kidney, without your permission. States Feser of Thomson's position: "...it isn't clear how it would justify any abortion other than in the case of pregnancy resulting from rape, with which the kidnapping by the violinist's admirers is analogous. Surely a pregnancy resulting from consensual intercourse - which, as everyone knows, has a chance of resulting in pregnancy even when contraception is used - is not analogous to Thomson's example." This is a telling point of Feser's, in that both the target of the violinist, and the woman who is pregnant as the result of rape, are placed in the position of host against their will. They are victims according to libertarian law, and the remedy, at the very least, ought to include saving them from their

\footnotetext{
1 FESER, Edward. Self-ownership, abortion, and the rights of children: toward a more conservative libertarianism. . Journal of Libertarian Studies, Auburn, vol. 18, n. 3, p. 91-114, june/sept. 2004.

2 For example, Feser focuses on "a moral difference with regard to the rape victim's obligations;" discusses how a woman "may morally extricate herself" from a predicament; and asks "Would it be morally permissible to destroy the protoplasm..."

3 The main connection between him and this essay of his on the one hand and libertarianism on the other is that it appeared in the Journal of Libertarian Studies, the flagship of this philosophy. Another linkage is that this author once considered himself a libertarian, but no longer does. See on that Feser (FESER, Edward. Self-ownership, abortion, and the rights of children: toward a more conservative libertarianism. . Journal of Libertarian Studies, Auburn, vol. 18, n. 3, p. 91-114, june/sept. 2004); also BLOCK, Walter E. Response to Feser on libertarianism. Journal Etica e Politica/Ethics \& Politics, Trieste. Forthcoming.

4 This author also indicates his support for positive obligations when he asserts: "Children, unlike the progeny of non-human animals, are entirely helpless at birth. It follows that, on libertarian principles, anyone who brings a child into the world has a duty to do what is necessary to provide for that child, since not to do so would be a clear violation of that child's self-ownership - a putting of that child in a position in which its capacities are completely nullified. Child neglect and endangerment, even when it is non-invasive, is an obvious violation of the SOP." (Self-Ownership Proviso.)

5 FESER, Edward.Self-ownership, abortion, and the rights of children: toward a more conservative libertarianism. . Journal of Libertarian Studies, Auburn, vol. 18, n. 3, p. 91-114, june/sept. 2004.

6 THOMSON, Judith Jarvis. A Defense of Abortion. Philosophy \& Public Affairs, New Jersey, vol. 1, n. 1, p. 6980, sept./dec. 1971.
} 
present plight. This means that the host of the violinist may cut him loose, and that the pregnant woman ought to be allowed to evict her unwanted fetus. ${ }^{7}$

But this analysis is marred by Feser's insistence that even in the case of rape the victim is precluded from separating herself from the fetus. He states:

If one accepts the SOP, then it is difficult to see how one can fail to condemn abortion, even in the case of rape, and certainly in the case of pregnancy resulting from consensual intercourse. A woman — and the man she sleeps with - are in the latter case like Adam, should he decide to fire cannonballs at passing ships and then complain that people keep washing up on his island whom he now has to allow ashore. ${ }^{9}$

The obvious reductio ad absurdum to this position, vis a vis Thomson, is that the violinist would then have a right to the use of your kidney for however long he needs it to maintain himself. For any lesser scholar than Feser, this would be enough to blow his theory out of the water. But this writer does not run away from this untenable implication of this theory. Rather, brazenly, he embraces it: "Accordingly, it would seem also to follow that you must remain attached to the violinist in Thomson's example...." It is difficult to deal with a philosopher who claims that the innocent person beset upon by the violinist must not cast him off. Is there such a thing as a super reductio ad absurdum, or, perhaps, the reductio ad absurdum squared, or, maybe, even, cubed? If followed to its logical conclusion, any criminal may do anything he wishes to any victim - up to and including rape, murder, enslavement - provided only that the perpetrator requires this action in order to maintain his well-being. Here we have a veritable clash of rights, something else that is anathema to the libertarian philosophy. For one person's well-being is set against that of another, and we are as at sea without a compass; we have no way of determining just who is in the right. It will not suffice, against Feser, to claim that the mother owns her womb, and that therefore the baby, no matter how innocent, is a trespasser, and that she is entitled to remove him from her premises. For if even the person victimized by the violinist may not separate from him, then no victim, no slave, no target of rape, may resist her attacker, so long as the latter is in great need of the physical body of the victim.

Feser also misconstrues Thomson's example of the "people seeds." She very properly uses this a defense against the charge that if a woman agrees to have intercourse,

\footnotetext{
7 We go along with both Feser and Thomson in positing, arguendo, that the fetus, at any stage of its development, is a rights-bearing human being.

8 Feser borrows this SOP from Mack (MACK, Eric. The Self-Ownership Proviso: A New and Improved Lockean Proviso. Social Philosophy and Policy, Cambridge, vol. 12, n. 1, jan./mar. 1995.). It is equivalent the common libertarian claim that we are all self-owners, and that therefore the initiation of violence against us would be illicit.

9 FESER, Edward. 2004. Self-ownership, abortion, and the rights of children: toward a more conservative libertarianism. . Journal of Libertarian Studies, Auburn, vol. 18, n. 3, p. 91-114, june/sept. 2004. p. 104.
} 
knowing that a possible result would be pregnancy, she still has not agreed, explicitly through contract, nor, even, implicitly, to house the baby for nine months. Her point was that if there were "people seeds" that could enter a home and create adult persons, and, if a woman opened her door or window and they got in and grew, she still would not be responsible to maintain them. Feser attempts to undermine this brilliant point of hers as follows: "Surely, though, the disanalogy here is obvious: sperm is hardly as difficult to avoid as Thomson's people seeds are, and unlike the latter, one has positively to do something to get it, something one is fully capable of refraining from. It is not as if we are, as with the people seeds, constantly bombarded with it." But this will not do. First of all, the different likelihoods of creating a baby in the ordinary way, or an adult in this science fiction-ish manner, should be irrelevant. We are talking principles here, not probabilities. Secondly, in both cases is it true that the woman must "do something to get it": agree to sexual relations, or, open a door or window.

What of evictionism? That entire idea nowhere enters into Feser's ken. And with "good" reason: if even the victim of rape must be compelled by law to keep her baby full term, then, for this author, no woman, for any reason, can be allowed to escape this fate. All that can be said about this analysis of Feser's is that it is difficult to reconcile with libertarianism. Does not the woman own her own womb? Not at all, for Feser.

\section{GOODWIN}

This author offers no fewer than thirteen arguments against evictionism. I intend to refute each and every one of them, despite the fact that this will call for some repetitiveness.10 Why? His libertarian credentials are impeccable. ${ }^{11}$ If even staunch libertarians such as this scholar cannot see their way clear to an understanding that evictionism is the only correct libertarian solution to the abortion debate, there is little hope than advocates of other philosophies will come to see it either. Therefore, it is imperative to pulverize his perspective.

\subsection{Abortion is killing, but is it murder?}

Well, I lied. In this section Goodwin merely summarizes Block and Whitehe$\operatorname{ad}^{12}$ and Rothbard 13 ; he does not yet launch into his critique. However, even in this

\footnotetext{
10 Several of his objections overlap one another.

11 Ordinarily, an author who writes a sentence of this sort would be expected to document it. I cannot do so, since "Goodwin" is a nom de plume. However, I am personally acquainted with this philosopher, and can vouch for his libertarian credentials.

12 BLOCK, Walter E.; WHITEHEAD, Roy. Compromising the Uncompromisable: A Private Property Rights Approach to Resolving the Abortion Controversy. Appalachian Journal of Law, Grundy, vol. 4, n. 1, 2005.

13 ROTHBARD, Murray N. The Ethics of Liberty. Atlantic Highlands: Humanities Press, 199/8.
} 
introduction of his, he writes: "Both have written in favor of abortion (Block via his concept of 'evictionism')..." The problem here is that this conflates eviction and abortion, two very, very different concepts. The first means, merely, that the woman can expel, detached from, separate herself from, the fetus, and leaves it as an entirely open question as to what will happen to her baby afterward. At present technology, the baby ${ }^{14}$ first becomes viable when treated in this manner in the third trimester. Abortion, in very sharp distinction, is entirely a separate matter. It combines two different acts: the first, eviction, and the second, outright murder. When a landlord evicts a tenant from his rental unit for non-payment, he does not execute him. If he does, this becomes an entirely different matter. Think of partial birth abortion in the last trimester as one of the most heinous activities humans have ever perpetrated on members of their own species. 15 The baby is perfectly capable of living outside of the womb. Yet, its brains are sucked out of it, and it is launched, dead, out into the open air. If that is not outright despicable murder, murder most foul, then nothing is. 16

\subsection{When does life begin?}

Behold, another lie on my part. Goodwin and I are entirely in accord on this matter; we both maintain that human life begins with the fertilized egg, he on the basis of a mere assumption, 17 me out of strong belief. 18 No one doubts the baby is a human at birth. But, a few moments before, while still in the womb? There does not seem to be too much of a difference between the two. And, if not, the step back toward the fertilized egg state is but a gradual one, with no obvious demarcation between human life and its absence. Of course, something similar may be said for the colors of the rainbow, ROYGBIV. They, too, shade into one another, and, yet, surely, we can demarcate, separately, each of these seven colors. I contend there is a disanalogy here. None of the colors "grow" into one another. They are separate entities. Not so for human development.

\footnotetext{
14 In an attempt not to set up a straw man argument, and, also, because this happens to be my view, I posit that human life begins with the fertilized egg. Neither the sperm alone, nor the egg alone, will in the ordinary course of things become a rights bearing human being; but, together, they will.

15 I abstract from cases where this procedure, and only this procedure, not eviction, is necessary to save the woman's life or for her health.

16 In saying this, I reveal where my own heart is at: strongly with the pro-life side of this debate. However, this perspective is incorrect, since it would not allow eviction in the first two semesters, when the fetus cannot live outside of the womb, and this is justified under evictionism.

17 He states: “... my examination proceeds assuming that human life begins at conception."

18 In the Jewish tradition, life begins when the fetus graduates from medical school. Well, when it has a heart-beat. But this seems arbitrary. Why not when it attains brain waves? Or a (semi) human shape? Or toes for that matter.
} 


\subsection{Abortion and failure to come to the aid}

Goodwin quotes me19 accurately, as follows: "The woman who refuses to carry her fetus to term is in exactly the same position as a person who refuses to rescue a drowning swimmer. Abortion is not, in and of itself, an act invasive of other people or their property rights, even when fetuses are considered persons." However, 120 misspoke. I should not have use the word "abortion" there. Rather, the word I should have used, and now do, is "eviction." So the sentences should read in this way: The woman who refuses to carry her fetus to term is in exactly the same position as a person who refuses to rescue a drowning swimmer. Eviction Abortion is not, in and of itself, an act invasive of other people or their property rights, even when fetuses are considered persons."

Goodwin claims a disanalogy here: "In the case of the drowning swimmer, the potential rescuer (presumably) did nothing to cause the swimmer to drown - the person did not throw someone unable to swim into the middle of the ocean after inviting the novice to go for a boat ride. However, the woman did take an action in the situation the act of becoming pregnant. Aborting the unborn child is like deliberately throwing a non-swimmer into the middle of the Pacific Ocean after providing a formal invitation to a nine-month cruise - a cruise with no scheduled stops. The invitation conveys an obligation; the act of throwing the person overboard is an aggressive act, in violation of the non-aggression principle."

I must of course agree with this gifted libertarian theorist when he points to the NAP as crucial to the analysis. However, I fear he errs in several places. First, he focuses on the fact that the woman "did take an action" to involve herself in this situation, while the boat owner was in no manner, way or shape responsible for the plight of the swimmer. Fair enough. However, merely "taking an action" does not logically imply responsibility for the results of that action. If a woman wears a mini skirt in some locales in Egypt, and more recently Cologne, Germany, she is likely to be molested, even raped. Is she responsible for that attack? Of course not. This would be entirely the fault of the person(s) committing the assault, not her. Just because the woman became pregnant obligates her to nothing whatsoever. Thomson furnishes us with yet another example. ${ }^{21}$ A woman opens her window. This makes it easier for a marauder to enter her property. Is she legally, ethically, responsible for the evil that ensues? Again, of course not, Goodwin to the contrary notwithstanding. Second what about rape? Here, the woman

\footnotetext{
19 BLOCK, Walter E.; WHITEHEAD, Roy. Compromising the Uncompromisable: A Private Property Rights Approach to Resolving the Abortion Controversy. Appalachian Journal of Law, Grundy, vol. 4, n. 1, 2005.

20 This sentence came from the section of that paper to which I contributed. Therefore the fault, the error, is mine.

21 THOMSON, Judith Jarvis. A Defense of Abortion. Philosophy \& Public Affairs, New Jersey, vol. 1, n. 1, p. 69-80, sept./dec. 1971.
} 
also "takes an action." She does not hire a bodyguard, and goes out for a walk, perhaps in a dangerous neighborhood. Is she therefore "responsible" for this crime? To ask this is to answer it. But I will answer it anyway: of course not.

\subsection{The unborn child is trespassing}

In this section our author objects to the by now famous Thomson violinist scenario as an analogy to pregnancy. He does so on the ground that the "mother took an action that could result (no matter the precaution taken) in pregnancy." Therefore, she is responsible to keep the baby with her for nine months. One problem is with the case of rape. The baby who results from that heinous act is as innocent as any other. Yet, it would appear that all babies have equal rights; certainly, Goodwin says nothing to the contrary. But if this is so, then it cannot be said that the woman victimized by rape "took any action" at all. Rather, she was acted upon. Again, also, going out on the street, or, even, entirely innocently sitting at home behind locked doors, "no matter the precaution taken" might result in a rape. This point of Goodwin's carries far less weight than he thinks it does. If staying at home or going out of one's home carries this risk, and the woman has therefore "acted," then, according to this author, she is "responsible." Reductio ad absurdum, anyone?

\subsection{There is no contract}

Goodwin maintains that it is indeed possible to have a contract with a baby, or a fetus. He quotes a legal authority to the effect that: "For most contracts, the general rule is that while it's not illegal to enter into a contract with a minor, the contract is voidable at the discretion of the minor. Voidable contracts are usually valid contracts and are binding unless the child cancels it." But this seems to stretch the meaning of a "contract" so far as to rend it asunder. A "minor" of, oh, eight or twelve years old is one thing. A fetus, is quite another.

\subsection{The mother can change her mind}

I can readily go along with Goodwin on this, if there is an iron clad contract between two parties, and one of them has already paid the other. This is the example offered by Rothbard regarding Smith and Jones; the former lends to the latter, and/or delivers a good to be paid for later.22 Then, there is a clear case of theft when the second party reneges. But the relation between mother and baby is so far removed from that type of situation as to make reliance on it completely invalid. Even if there were an

22 See below under topic ten. 
invitation from the mother to the unborn baby, which there is not, people are allowed, at least under libertarian law, to change their minds regarding them. Of course, you may not invite someone for a sea cruise, and then, 500 miles from shore, change your mind about the invitation and ask the guest to leave. Here, there is an implicit contract that the host will leave the guest in no worse position, vis a vis his life expectancy, than before the invitation was made. But, again, it is a herculean stretch to equate that with the relation of mother and fetus. In any case, the fetus is not created until some time after sexual intercourse is completed. There is no small human being inside the womb until the sperm enters the egg several minutes afterward. Thus, at the time of the congress between man and woman, there is no fetus yet in existence who can possibly be "invited."

\subsection{Evictionism}

The underlying idea behind evictionism is that the unwanted zygote is a trespasser, no matter how he ended up in the womb, and the mother, the owner of her body, has a right to evict, but not murder, this young interloper.

Goodwin disagrees: "I find no trespass. How is one trespassing when one was invited? When the party host extended the invitation, she knew it would be for a nine-month visit with no possible way for the guest to depart in the meantime. The unborn child was invited by the action of the woman for just such a term." There are problems here. First, there was no invitation. Certainly, not in the case of rape. Second, even if there was an invitation, which there most certainly was not, it need not be for a "nine-month visit." Contrary to Goodwin, the baby is viable outside the womb at the seventh month. Why not an invitation for a week or so, or a month at most? Where is it written that all pregnant women offer invitations for three quarters of a year?23

It is at this point that Goodwin commits a philosophical howler. He starts off by quoting from: "The position put forth here, in contrast, is one of eviction not of killing. However, if the only way to evict is by killing the fetus, then the woman's right to her property - that is, her womb - must be held above the valuable life of the fetus." 24

He then continues: "There is significant fault with this assertion. Even if one grants Block's position, Rothbard suggests that property rights can be legitimately defended only proportionately: 'The victim, then, has the right to exact punishment up to the proportional amount as determined by the extent of the crime..."'

\footnotetext{
23 I pick up a hitch-hiker in New Orleans. He wants to go to Los Angeles. I agree to take him there. But then when we get to Houston, I change my mind and ask him to leave. Have I committed a crime? Not any that would be recognized by a libertarian court.

24 BLOCK, Walter E.; WHITEHEAD, Roy. Compromising the Uncompromisable: A Private Property Rights Approach to Resolving the Abortion Controversy. Appalachian Journal of Law, Grundy, vol. 4, n. 1, 2005.
} 
The mistake is to equate defense and punishment. Not only in libertarian law is the victim able to do much more to protect himself during the commission of the crime than the court may do after the fact, if it supports the libertarian notion of proportional punishment. While the crime is being committed, the victim has no idea as to whether or not deadly force will be used by the perpetrator. The latter may only want to steal a can of beer, but the grocer cannot know that. Thus, he is entitled to kill the intruder. In contrast, it would not be a civilized court that would impose the death penalty for such petty theft.

Whereupon this author offers a very important challenge to libertarian theorists. He asks: "Is a shopkeeper justified in shooting a six-year-old child in the back while the child is escaping with a one-dollar candy bar? It seems Block and Whitehead would say yes. After all, it is the shopkeeper's property rights in question. Does the six-year-olds' aggression justify any and every level of violence by the shopkeeper in defending his one-dollar candy bar?" I speak only for myself when I say that the only time this would be justified is if the only way the shopkeeper could stop the theft is by shooting. For example, he might be a paraplegic with only the trigger finger functioning. For the libertarian, property rights are sacrosanct. We cannot support children stealing candy bars; if we do, utilitarian point coming up, the practice will become widespread. Assuming the child is young enough not to constitute a threat, the mighty presumption is that the able-bodied property owner will be able to stop the theft with far less violence than the proverbial shot in the back; certainly, such a baby constitutes no threat of bodily harm. The reason he may do so to an adult, or, even, an armed child, is that, then, there is a threat of dire consequences, and if property rights are to be upheld, then force, yes, deadly force, is justified.

\subsection{Rights of the unborn child}

In this short section our author likens the relationship of mother and unborn baby to that between landlord and tenant. This seems like a bit of a stretch, even for Goodwin, since the former never signed a lease, no monthly fees were ever paid, etc.

\subsection{Causation}

My protagonist here maintains that the woman was a causal agent in her pregnancy, and that people are always responsible for what they cause; in effect they must set things right; be accountable, answerable for what they unleash. He states: "Here I speak to causation not in the abortive act (although this could be used to counter Block's "evictionism" argument), but in conception. The woman's "conduct" during intercourse brought on the "result" of pregnancy. It is difficult to accept that the woman 
somehow has no responsibility at all for the pregnancy (and therefore, the unborn child) directly caused by her conduct."

There is so much wrong here it is hard to know where to begin. Let us start with the fact that the other day I purchased an apple. I'm a relatively big eater of this fruit. This "caused" the price of apples to rise. My "conduct" thus "resulted" in the fact that some other person, a marginal consumer, got priced out of the market and could no longer afford to make a purchase he otherwise would have made. I am thus "responsible" for this "conduct" of mine. The implication would appear to be that I owe this person an apple, or, at the very least, an amount of money equal to the difference between what he would have paid for it in the absence of my "conduct" and with its presence. "Preposterous" would appear the only possible response to any such claim, however. Or, take another case. You don't ask the ugly girl to dance at the party. As a "result" she commits suicide. You "caused" this, you dirty rat, you. Contrary to fact conditional stipulated: had you asked her for even one dance, she would have been a happy camper, very far removed from doing herself in. My response to all of this? Cause schmause. Causing something may well be necessary for having committed a crime, but it is certainly not sufficient, as Goodwin's analysis would have it.

\subsection{Reasonable reliance (on promises)}

Rothbard discusses the "title-transfer" theory of contracts as follows:

Suppose that Smith and Jones make a contract, Smith giving $\$ 1000$ to Jones at the present moment, in exchange for an IOU of Jones, agreeing to pay Smith $\$ 1100$ one year from now. This is a typical debt contract. What has happened is that Smith has transferred his title to ownership of $\$ 1000$ at present in exchange for Jones agreeing now to transfer title to Smith of $\$ 1100$ one year from now. Suppose that, when the appointed date arrives one year later, Jones refuses to pay. Why should this payment now be enforceable at libertarian law? Existing law (which will be dealt with in greater detail below) largely contends that Jones must pay $\$ 1100$ because he has "promised" to pay, and that this promise set up in Smith's mind the "expectation" that he would receive the money.

Our contention here is that mere promises are not a transfer of property title; that while it may well be the moral thing to keep one's promises, that it is not and cannot be the function of law (i.e., legal violence) in a libertarian system to enforce morality (in this case the keeping of promises). Our contention here is that Jones must pay Smith $\$ 1100$ because he had already agreed to transfer title, and that nonpayment means that Jones is a thief, that he has stolen the property of Smith. In short, Smith's original transfer of the $\$ 1000$ 
was not absolute, but conditional, conditional on Jones paying the $\$ 1100$ in a year, and that, therefore, the failure to pay is an implicit theft of Smith's rightful property.

Let us examine, on the other hand, the implications of the now prevalent 'promise' or 'expectations' theory of contracts. Suppose that $A$ promises to marry $B ; B$ proceeds to make wedding plans, incurring costs of preparing for the wedding. At the last minute, A changes his or her mind, thereby violating this alleged 'contract.' What should be the role of a legal enforcing agency in the libertarian society? Logically, the strict believer in the 'promise' theory of contracts would have to reason as follows: A voluntarily promised $B$ that he or she would marry the other, this set up the expectation of marriage in the other's mind; therefore this contract must be enforced. A must be forced to marry $B$.

As far as we know, no one has pushed the promise theory this far. Compulsory marriage is such a clear and evident form of involuntary slavery that no theorist, let alone any libertarian, has pushed the logic to this point. Clearly, liberty and compulsory slavery are totally incompatible, indeed are diametric opposites. But why not, if all promises must be enforceable contracts?

A milder form of enforcing such marriage promises has, however, been employed, let alone advocated, in our legal system. The old 'breach of promise' suit forced the violator of his promise to pay damages to the promisee, to pay the expenses undergone because of the expectations incurred. But while this does not go as far as compulsory slavery, it is equally invalid. For there can be no property in someone's promises or expectations; these are only subjective states of mind, which do not involve transfer of title, and therefore do not involve implicit theft. They therefore should not be enforceable, and, in recent years, 'breach of promise' suits, at least, have ceased to be upheld by the courts. The important point is that while enforcement of damages is scarcely as horrendous to the libertarian as compulsory enforcement of the promised service, it stems from the same invalid principle. 25

If this does not put paid to Goodwin's promises theory, then nothing will. But this author demurs on the following ground: "What would a reasonable person - one unable to swim - assume if invited on a nine-month ocean cruise? Would he reasonably assume this invitation included the possibility that his hostess would throw him overboard?

25 ROTHBARD, Murray N. For a New Liberty: The Libertarian Manifesto. Auburn: Ludwig von Mises Institute, 1973. chapter 19. 
"After receiving an invitation that inherently involved nine months of complete - life-and-death - dependency, what would be more reasonable for the unborn child to rely upon than he was promised the benefit of the full term in the womb?"

But there is a hole in this analogy large enough to drive through it the proverbial truck. The boat owner explicitly invited the non-swimmer guest on a cruise; the mother made no such invitation to the baby. At the time of intercourse, no fetus yet existed. An invitation requires two parties, and inviter and an invitee. Surely, in the case of rape there could not have been any invitation at all, not even a poetic one of the sort imagined by this author. In the case of the shipping magnate, there was at least an implicit understanding that the guest would not be treated in so cavalier a manner. If he was, his welfare position would have been worsened, and he would not have agreed to embark on the trip in the first place. In the case of the pregnant woman who evicts her baby, whether or not it perishes, the latter's position was improved if we can claim that existence even for a short time is better than no existence at all.26 Nor is there any question of a not yet existing fetus agreeing to anything.

\subsection{A unilateral contract}

But Goodwin is not finished yet. Far from it. He brilliantly offers the following scenario to overcome the fact that at the time of sexual intercourse, there is no fetus (yet) in existence:

Offering a reward is a typical example of such a contract - a reward is made known to the general public. The counterparty need not be known at the time the contract is offered, yet it is enforceable by the counterparty if properly claimed. Technically, the counterparty need not even be born or conceived when the offer was made (imagine in 1963 a fifteen-year-old boy finding Hitler on skis in Bariloche). Subsequently, someone comes to claim the reward: the person who chose to act. Although he was not the individually identified counterparty (at the time of contract there was no specific counter-party), he has a contractual right to the reward.

It cannot be denied that this author is ingenious. But, try as he might, he will not be able to overcome the case in favor of evictionism. For offering a reward is making a promise to pay. There is no contract involved. And, Rothbard's dismissal of contracts as legally 27 binding is definitive. Remember, in a contract, where consideration has

\footnotetext{
26 Further, "where there is life there is hope." Which position would you rather occupy, gentle reader? Never to have been conceived at all, or, to have been created, with a chance at life if the mother carries through, or not, if she evicts before viability? For those who chose existence, the answer is obvious.

27 Not morally.
} 
changed hands, reneging amounts to downright theft. No such situation occurs with a broken promise.

But will this not end the practice of offering rewards? That is, promising to pay any (now unknown person) money or valuable consideration if he fulfills the requirement? Not at all. The promisor need only post a bond with a third person, perhaps a bank, or a court, to the effect that the person who complies with the mandate of the reward shall be paid. Then it is out of the hands of the person who made the promise.28 Suppose Rothbardianism in this regard were to become the law of the land. Bonds of this sort would tend to assure subsequent payment of the reward.

Not only is Goodwin a brilliant libertarian theoretician, he is a poet of no little note. Consider the following:

The woman made an offer; she placed herself in a position of being obligated to a counter-party that might take her up on her offer. The unborn child took her up on the offer, and can therefore enforce the contract - contracts with minors are enforceable by the minor, if the minor chooses to do so; contracts with a minor can only be voided by the minor. I suspect the unborn child would choose to enforce the contract.

Yes, these words are beautiful. But they avail his side of the argument nothing when the rubber hits the road. No, the woman never made her (not yet existing) fetus an offer. ${ }^{29}$ This claim is poetic only. In real terms, preposterous. No, the unborn child most certainly did not "take her up on her offer." Only in sublime poetry can non-existent entities "take any one up" on anything. There was no "contract" between them, except poetically. Unborn children are not yet capable of "choosing" anything, except in fairy tales. The soon to be mother offered a "reward" to her soon to be created baby? This is but the product of a very fertile imagination.

\subsection{Lease}

If any plain old ordinary contract is nonsense, then a real estate lease is nonsense on stilts. And, yet, Goodwin sees "The mother as landlord and the unborn child as tenant have entered into a lease - a fixed-term tenancy, with the term tied to a specific event: birth. Such a lease term was recognized in common law." When, ever, did the "tenant" pay rent to the "landlord"? Never, that is when.

\footnotetext{
28 But are we not, merely, placing the problem at one remove, attempting, as it were, to sweep it under the carpet? No. For this third party would be contractually obligated insofar as the reward giver is concerned, to make the money available to anyone complying with the stipulations of the reward. If this third party reneged, he would in effect be stealing money from the person who offered the reward, in much the same way, in Rothbard's example, as Jones stole from Smith.

29 This holds in spades for the woman who is pregnant as a result of rape, who's fetus has every right enjoyed by any other not yet born infant.
} 
Our author asks: "Can the landlord evict the tenant without cause? I have reviewed several typical real estate lease contracts, and find nothing to suggest this is so." If there is a signed lease by both parties, then, of course, neither can abrogate it without the other's permission. But this business of "without cause" stems from the realm of rent control. There, the landlord would like nothing better than to evict the tenant who is paying below market rent. 30 But the law will not allow the property owner to do any such thing, lest this totally undermine the rent control system at the outset.

\subsection{Covenant of quiet enjoyment}

Borrowing heavily, again, from real estate law, Goodwin requires of "the landlord (the mother)" that she provide her tenant, the baby, with quiet enjoyment of the premises she has rented out to him. Certainly, he avers, this would feature the exclusion of "an abortion doctor from the premises" as this be the very opposite of "peace and quiet" for the tenant. But it would include much more. Under this "agreement," presumably, the mother would not be allowed to drink alcohol, smoke cigarettes, engage in strenuous sporting events, fail to get plenty of rest, etc. There is no objection to the fact that ethically speaking, these are all required. But Goodwin would make this a matter of law, libertarian law. One wonders how many mothers would be willing to sign a "real estate" "contract" of this sort.

\section{MOSQUITO}

Mr. Mosquito31 "agrees with the vast majority of Walter Block's positions on the application of the non-aggression principle to the various concerns of the humans that inhabit this planet." I am pleased and proud to acknowledge the inverse. I regard this scholar as one of the most gifted libertarian theoreticians now active on a whole host of issues related to the NAP. Moreover, I am impressed that he should use specific performance contracts, something on which we both agree, against my views on evictionism.

What are specific performance contracts? These are agreements when the employee must carry through on the performance mentioned in the contract. For example, $A$ hires $B$ to sing at his wedding. $B$ changes his mind. $A$ is legally entitled to compel $B$ to engage in that act. The most extreme case of this would be the voluntary slave contract. $B$ sells himself to $A$ as a slave. A now has the legal right to whip $B$ for any reason. If $B$ calls the police and accuses $A$ of assault and battery and given that this specific performance contract is legal, then the police will not and may not come to the aid of $B$.

\footnotetext{
30 Either he can rent it to another tenant at a higher rate, if allowed by law, or, convert it to a more remunerative purpose, typically sell it as a condominium.

31 Another gifted libertarian who writes under a pseudonym whose identity I decline to reveal.
} 
If $B$ attempts to run away from $A$, the police will properly bring $B$ back into the custody of $\mathrm{A} .32$

Mosquito, who agrees with me on the validity of such contracts, brilliantly attempts to employ them against my evictionist position. He argues that the fetus has a

32 Virtually all libertarians oppose specific performance contracts, and, certainly slave contracts as mentioned above. Here is but the tip of the iceberg in this regard: BARNETT, Randy E. Contract Remedies and Inalienable Rights. Social Philosophy \& Policy, Cambridge, vol. 4, issue 1, p. 179-202, sept./dec. 1986; BARNETT, Randy E. The Structure of Liberty: Justice and the Rule of Law, Oxford: Clarendon Press, 1988; CALABRESI, Guido; MELAMED, Douglas. Property Rules, Liability Rules, and Inalienability: One View of the Cathedral. Harvard Law Review, Cambridge, vol. 85, n. 6, p. 1089-1128, apr. 1972.; EPSTEIN, Richard. Why Restrain Alienation. Columbia Law Review, New York, vol. 85, p. 971-990, 1985; EVERS, Williamson. Toward a Reformulation of the Law of Contracts. Journal of Libertarian Studies, Auburn, vol. 1, p. 3-13, jan./mar. 1977; GORDON, David. Private Property's Philosopher. The Mises Review, Auburn, vol. 5, n. 1, p. 1-7, mar./june 1999; KINSELLA, N. Stephan. Inalienability and Punishment: A Reply to George Smith. Journal of Libertarian Studies, Auburn, vol. 14, n. 1, p. 79-93, dec./mar. 1998-99; KINSELLA, N. Stephan. A Libertarian Theory of Contract: Title Transfer, Binding Promises, and Inalienability. Journal of Libertarian Studies, Auburn, vol. 17, n. 2, p. 11-37, mar./june 2003; KRONMAN, Anthony. Paternalism and the Law of Contracts. Yale Law Journal, New Haven, vol. 92, 1983; KUFLIK, Arthur. The Inalienability of Autonomy. Philosophy and Public Affairs, New Jersey, vol. 13, n. 4, p. 271298, mar./june 1984; KUFLIK, Arthur. The Utilitarian Logic of Inalienable Rights. Ethics, [s.l.], vol. 97, p. 75-87, oct. 1986; MCCONNELL, Terrance. The Nature and Basis of Inalienable Rights. Law and Philosophy, [s.I.], vol. 3, n. 1, p. 25-59, 1984; MCCONNELL, Terrance. The Inalienable Right of Conscience: A Madisonian Argument. Social Theory \& Practice, [s.l.], vol. 22, issue 3, p. 397-416, mar./june 1996; RADIN, Margaret Jane. Time, Possession and Alienation. Washington University Law Quarterly, Washington, vol. 64, n. 3, p.739-758, 1986; RADIN, Margaret Jane. 1987. Market-Inalienability. Harvard Law Review, Cambridge, vol. 100, n. 8, p. 1849-1937, june 1987; REISMAN, George. Capitalism. Ottawa: Jameson Books, 1996. p. 455, 634-636; RICHMAN, Sheldon. Slaves contracts and the inalienable will. The Libertarian Forum, Auburn, p. 4-5, jul./aug., 1978. Available at: $<$ http:// mises.org/journals/ff/1978/1978_07-08.pdf>; ROTHBARD, Murray N. The Ethics of Liberty. Atlantic Highlands: Humanities Press, 1998; SMITH, George. A Killer's Right to Life. Liberty, [s.l.], vol. 10, n. 2, p. 46-54, nov. 1996; SMITH, George. Inalienable Rights? Liberty, [s.l.], vol. 10, n. 6, p. 51-?, jul. 1997.

However, there are a few counter examples: ANDERSSON, Anna-Karin. An alleged contradiction in Nozick's entitlement theory. Journal of Libertarian Studies, Auburn, vol. 21, n. 3, p. 43-63, mar./june 2007; BLOCK, Walter E.. Voluntary Slavery. The Libertarian Connection, [s.l.], vol. I, n. 3, p. 9-11, apr. 1969; BLOCK, Walter E. Book review of Nancy C. Baker, Baby Selling: the Scandal of Black Market Adoptions, New York: The Vanguard Press, 1978. Libertarian Review, San Francisco, vol. 7, n. 12, p. 44-45, jan. 1979; BLOCK, Walter E. Market Inalienability Once Again: Reply to Radin. Thomas Jefferson Law Journal, San Diego, vol. 22, n. 1, p. 37-88, mar./june 1999; BLOCK, Walter E. Alienability, Inalienability, Paternalism and the Law: Reply to Kronman. American Journal of Criminal Law, Austi, vol. 28, n. 3, p. 351-371, june/sept. 2001; BLOCK, Walter E. Toward a Libertarian Theory of Inalienability: A Critique of Rothbard, Barnett, Gordon, Smith, Kinsella and Epstein. Journal of Libertarian Studies, Auburn, vol.17, n. 2, p. 39-85, mar./june 2003; BLOCK, Walter E. Ayn Rand and Austrian Economics: Two Peas in a Pod. The Journal of Ayn Rand Studies, University Park (PA), vol. 6, n. 2, p. 259-269, mar./june 2005; BLOCK, Walter E. Epstein on alienation: a rejoinder. International Journal of Social Economics, [s.l.], vol. 33, n. 3-4, p. 241-260, 2006; BLOCK, Walter E. Alienability: Reply to Kuflik. Humanomics, [s.l.], vol. 23, n. 3, p. 117-136, 2007; BLOCK, Walter E. Yes, Sell Rivers! And Make Legal Some Slave Contracts. The Tyee,, Victoria, Opinion, July 25 2009. Available at: http://thetyee.ca/Opinion/2009/07/24/SellRivers/; BLOCK, Walter E. Privatizing Rivers and Voluntary Slave Contracts. Lew Rock Well, [s.l.], July 27 2009, Available at: <http://www.lewrockwell.com/ block/block134.html>; FREDERICK, Danny. Voluntary Slavery. Las Torres de Lucca, Madrid, vol. 3, n. 4, p. 115137, ene./jun. 2014; KERSHNAR, Stephen. A Liberal Argument for Slavery. Journal of Social Philosophy, [s.l.], vol. 34, n. 4, p. 510-536, 2003; LESTER, Jan Clifford. Escape from Leviathan. New York: St. Martin's Press, 2000; MOSQUITO, Bionic. Walter Block, Specific Performance Contracts, and Abortion. July 12 2015. Available at: $<$ http://bionicmosquito.blogspot.com/2015/07/walter-block-specific-performance.html>; MOSQUITO, Bionic. The Sanctity of Contract. April 19 2014. Available at: <http://bionicmosquito.blogspot.com/2014/04/the-sanctity-of-contract.html>; NOZICK, Robert. Anarchy, State and Utopia. New York: Basic Books, 1974. p. 58; 283; 331; STEINER, Hillel. An Essay on Rights. Oxford: Blackwell Publishers, 1994. p. 232; THOMSON, Judith Jarvis. The Realm of Rights. Cambridge: Harvard University Press, 1990 p. 283-284. 
right to insist that the mother engage in the specific performance she had contractually obligated to undertake, that is, "house" him safely for the usual nine month duration. Specifically he maintains: "I suggest that the unborn child has the right to the use of the womb for the term of the pregnancy. The mother owns the womb (obviously), but the child is a tenant, if you will; a tenant who in no way breached the lease agreement..." Mosquito refers to "Block's ... (view) ... regarding specific performance contracts outlining the right of the counter-party to demand specific performance if the first party has a change of heart.... he disagrees with those in the libertarian community who suggest that such contracts are invalid within the framework of the NAP. He believes that enforcement of the terms of a specific performance contract is perfectly legitimate within libertarian theory... What does this have to do with abortion? One of the types of contracts upon which I make my case regarding the unborn child's rights to occupy the womb for the term of the pregnancy - and against the possibility of eviction - is a specific performance contract."

This attempt to hoist me by my own petard is insightful. However, I contend, it fails. It is predicated upon there being a specific performance or any other contract in existence between mother and baby. In my response to Goodwin, supra, I outline my reasons for doubting the existence of any such contract between these two "parties."

Mosquito concludes his short essay on this note: "If the mother changes her mind - as Rothbard suggests she has every right to do - it will cause irreparable harm to the unborn child. Money damages will most certainly not be sufficient for the benefit of the now-dead unborn child. The counter-party (the unborn child) would be entitled to equitable relief, including specific performance, and such relief shall not be opposed. What specific performance would the unborn child demand? It is not difficult to imagine the answer.

Similar language is included in many contracts today, and one would expect in this most one-sided contract between mother and unborn child - where the party that set the terms of the contract could then break the contract and realize a gain while the counter-party suffers death - it seems reasonable that the expectation would be not less than what is standard in every-day commercial agreements - for exchanges much less significant than life and death.

However, again, this entire line of reasoning, brilliant as it is, founders on the fact that there is no contract, there can be no contract, of any kind, between mother and the sperm and the egg, which are the only entities that exist at the time of voluntary sexual intercourse. Even if we posit that there can be a contract between the mother and the pre-born infant, an entirely heroic assumption this is not sufficient to support the Mosquito's contention. 


\section{SADOWSKY}

Sadowsky33 is a response to Block ${ }^{34}$. Although both were published several decades ago, each is an integral part of the libertarian literature on abortion, and thus part and parcel of the present treatment.

This author objects to the evictionist thesis on the ground that most abortions do not fit this model: "What is wanted in most cases is precisely the death of the child. Most of those seeking abortions would be horrified at the thought that the child might survive his expulsion." Here, Sadowsky does not realize it, but he and I have no disagreement at all. Remember, abortion is the combination of two very different acts: separation, which may or may not be compatible with the viability of the fetus outside of the womb, it all depends upon which month this occurs; and, something altogether dissimilar: the actual killing (murder!) of the baby. It is precisely the essence of evictionism that while the first aspect of this double edged act is justified, the second part most certainly is not. The point is that in the first two trimesters, evictionism and pro-choice have the same effect, albeit for different underlying reasons: the fetus dies. In the third trimester, evictionism and the pro-life philosophy overlap in terms of practical results, if not philosophical underpinnings: the baby lives. And, as medical technology marches ever onward, evictionism comes more and more to resemble the pro-life position, at least in terms of whether the fetus survives or not. That is, for every ten or twenty years of new medical technology that passes, the fetus will be viable outside of the womb a few days earlier. Perhaps in 50 years from now, the fetus may be able to live outside the womb as early as its sixth month of existence; maybe in 100 years, in the fifth month. Does anyone doubt that in a century or two, or a millennium or so for the pessimists, the womb will no longer be needed to support the fertilized egg at all?

Sadowsky then asks:

Does the mere fact that a man is a stowaway justify our throwing him out of the aircraft? Ought we not in the absence of overriding reasons to wait until the aircraft lands? Both traditional natural law theory and the common law have it that our response to aggression should be proportionate to our need to resist and the nature of the attack. Suppose that the inflicting of a lethal wound is the only way to recover a stolen nickel. Is that enough to justify such an act?

Consider the stowaway first. He is a danger to the airplane owner. Who knows of what malicious acts he is capable. But, let us place this case in the best light possible.

33 SADOWSKY, James. Abortion and Rights of the Child. The Libertarian Forum, Auburn. p. 2-3, jul./aug. 1978. Available at: <http://mises.org/journals/lf/1978/1978_07-08.pdf>.

34 BLOCK, Walter E. Toward a Libertarian Theory of Abortion. The Libertarian Forum, Auburn, vol. 10, n. 9, p. 6-8, sept. 1977. 
He is unconscious. 35 Better yet, and more analogous, he is a totally innocent stowaway, who has been drugged and placed in your airplane by an evil gang. Then, does he not have a right to be expelled only after the landing of the plane? Whether or not this is true, the analogy with the baby, the purpose to which Sadowsky is employing this example, does not hold. For there is all the world of difference between trespassing into an airplane, and into the body of a person. Rothbard says this very dramatically: “... just as an assault on someone's body is a more heinous crime than the theft of his property, so the trespassing on or within a person's body is a far more heinous trespass than merely strolling on his land or stowing away on an aircraft." 36

Then, too, Sadowsky is guilty of the error of equating what may be done to the perpetrator when he is in the act of committing his dastardly crime, on the one hand, with how he may be properly punished afterward, when in the clutches of the law. Proportionality may well apply in the latter case, but certainly not in the former. Then, all bets are off. The victim may use deadly force to protect himself, and, I would add, his property, down to and including nickels stolen from him, forsooth. ${ }^{37}$ Sadowsky, as a libertarian, accepts the centrality to this philosophy of the NAP. But, what good does this concept do if an owner may not use force to protect his five cent coin? Either we have the NAP or we do not. If we do, we may not only own property, but defend it too.

Again, Sadowsky confuses abortion and eviction when he writes: "... the foetus does not die as the result of the mother's failure to extend the means of life - it dies of the attack itself." True, always, for abortion, but this holds, for eviction, only in the first six months of the pregnancy. In the last three months, the fetus need not perish. Indeed, it can survive outside of the womb in this stage of development.

We cannot ignore two more of Rothbard's salient critiques of Sadowsky. Says the first:

... even if the foetus is considered to be human, no human has the right to reside unwanted within the body of another." And, with regard to Thomson's victim of the violinist: "I say that you would have the right, not merely to unplug yourself from his kidneys, but to be damned 'brutal' about it if necessary to get your body out of its enslavement, even if it kills the pianist in the process. 38

However, I must demur from Rothbard when he avers:

\footnotetext{
35 The unconscious stowaway can wake up at any time, and create havoc, even more dangerous in the air. We can then stipulate that this worthy is placed in handcuffs, and thus can perpetrate no harm.

36 ROTHBARD, Murray N. The editor replies. The Libertarian Forum, Auburn, p. 3, jul./aug. 1978. Available at: <http://mises.org/journals/lf/1978/1978_07-08.pdf>.

37 Although see the discussion of the paraplegic mentioned supra, in the discussion of Goodwin's point 7.

38 ROTHBARD, Murray N. The editor replies. The Libertarian Forum, Auburn, p. 3, jul./aug. 1978. Available at: <http://mises.org/journals/lf/1978/1978_07-08.pdf>.
} 
It seems to me that the problem with the Block-Sadowsky thesis of asserting the foetus to be human is that that act of birth, which I had always naively assumed to be an event of considerable importance in everyone's life, now takes on hardly more stature than the onset of adolescence or of one's 'mid-life crisis.' Does birth really confer no rights?" My response is, No, birth really confers no rights; none, in any case, not owned by the fetus five minutes before birth. Further, this event is of far less importance than "the onset of adolescence or of one's 'mid-life crisis.' 39

Rather, it is akin to a mere change of address, for that is all that happens in the few seconds before and after birth: a change of address, slight in the geographical sense, momentous insofar as dependency on the mother is concerned.

\section{VANCE}

In this section I respond to Vance40; I consider them in reverse order. Vance's 2012 article is entitled "Libertarianism and Abortion." He and I both favor the former and oppose the latter. One wonders, then, why I would include his fascinating and very important contributions to this vexing issue since we seem to be in full agreement, if it is not my goal to merely to underscore everything he writes about it. However, our agreement is more apparent than real. About libertarianism, itself, nothing more need be said. We are fully congruent on that issue; I am an enthusiastic supporter of his views on that issue.

But he and I oppose abortion for very different reasons. In his case, it is because he is pro-life. In mine, it is because I make a sharp distinction between abortion, which combines eviction with outright and downright murder, and eviction alone. I oppose abortion not due to the first aspect (eviction) of this complex act, but rather the second (murder). Vance's stance on eviction, as distinct from abortion, is ambiguous. He states: "... how far along the pregnancy has to be ..." so as to justify for eviction a criminal penalty "... are things that would have to be determined that I don't profess to have precise answers to. But this is precisely the point of contention between evictionists and pro-lifers. Thus this author therein declares himself in effect an agnostic on evictionism, not an opponent of this philosophy. Nevertheless, a careful study of his essential deliberations on this subject will pay great dividends.

39 ROTHBARD, Murray N. The editor replies. The Libertarian Forum, Auburn, p. 3, jul./aug. 1978. Available at: <http://mises.org/journals/lf/1978/1978_07-08.pdf>.

40 VANCE, Laurence. Is Ron Paul Wrong on Abortion? Lew Rock Well, [s.I.], January 29 2008. Available at: http:// archive.lewrockwell.com/vance/vance133.html; VANCE, Laurence. Libertarianism and Abortion. Lew Rock Well, [s.l.], July 17 2012. Available at: <http://archive.lewrockwell.com/vance/vance297.html>. 
Vance starts out on a high note for a libertarian, centering this philosophy on the NAP41: "I have argued that because the non-aggression axiom is central to libertarianism, and because force is justified only in self-defense, and because it is wrong to threaten or initiate violence against a person or his property, and because killing is the ultimate form of aggression that, to be consistent, libertarians should be opposed to abortion." 42 Yes, indeed, "libertarians should be opposed to abortion" but not to mere eviction, even though, unfortunately, if done too early in the pregnancy, the very human baby will perish.

Next, consider this statement of Vance's:

Because a child in the womb is helpless, not initiating violence, not committing aggression, and not there of its own accord, I believe that, to be consistent, libertarians should not only be opposed to abortion, but in favor of making it a criminal act just like murder, rape, kidnapping, theft, assault, and robbery would be in any libertarian society based on the non-aggression principle. 43

Helpless? Yes. Initiating violence? No, of course not. Not there of its own accord? Again, I agree. But the unwanted fetus is still committing aggression, in that he is occupying someone else's property, against her will. In the case of rape this is all too clear. It cannot be denied that such an infant is indeed a trespasser, albeit, of course, one lacking mens rea. Yet, all babies, however they were conceived, have equal rights. If this fetus may be ejected, then that applies to all of them. Yes, abortion should be a criminal act, but not eviction. In addition to not knowing how to deal with "... how far along the pregnancy has to be ..." Vance is not sure of the libertarian analysis of rape. But this seems very clear to me. It is unimaginable that such a baby should not be considered an interloper by the libertarian, no matter how undeniably innocent he is in terms of culpability. Thomson's violinist is equally innocent, and at one and the same time, an interloper.

Vance continues his analysis:

... although a fetus is a parasite in the sense that it lives inside, is dependent upon, and obtains nutriments from a host, I hasten to point out that a newborn baby is totally dependent upon someone to feed and take care of it as well. Even a six-month-old baby left to itself will soon die. Is it okay to just throw parasitical children in the trash with aborted

41 Quite properly, Vance quotes Mr. Libertarian on this matter, Murray Rothbard, and is even kind enough to include my own forays into this issue. He characterizes me as "Rothbard's disciple" and no truer words were ever said.

42 VANCE, Laurence. Libertarianism and Abortion. Lew Rock Well, [s.I.], July 17 2012. Available at: <http:// archive.lewrockwell.com/vance/vance297.html>.

43 VANCE, Laurence. Libertarianism and Abortion. Lew Rock Well, [s.I.], July 17 2012. Available at: <http:// archive.lewrockwell.com/vance/vance297.html>. 
babies? A child in the womb a week before birth is just as much a parasite as a child in the womb six months before birth. Are libertarians who advocate abortion on demand ready to allow the procedure at any time before birth in the name of consistency? ${ }^{44}$

Dependency is an entirely different matter than parasitism. We can readily acknowledge that the newborn and the preborn baby are equally dependent upon adult care. And the same applies to the fetus in all stages of its development. But it is not true that the post birth baby is at all a parasite, as is the (unwanted) one in the womb. As a libertarian, I do not at all advocate "abortion on demand" but I do maintain that eviction "on demand" is compatible with this philosophy. Nothing stated by Vance so far is necessarily at variance with such a conclusion, although he certainly does not explicitly support such a stance.

But all this changes with his perspective, which is now incompatible with evictionism: "When a woman engages in an activity the natural consequence of which is pregnancy, she is obligating herself to bring to term a completely separate individual with uniquely different DNA that didn't choose to 'invade' her body or 'aggress' against her." Does the woman victimized by rape "engage" in sexual intercourse? This is unclear. If so, then she certainly does not "obligate" herself to anything. As for the female who voluntarily chooses to participate in this act, she no more obligates herself to anything at all, any more than does Thomson's woman who opens a door or window and thus makes it easier for the burglar to attack her. The "natural consequence" of a woman who walks out alone, unescorted by a male relative in some Arab countries, is to be raped, and perhaps impregnated. The "natural consequence" of a female who dresses in revealing clothing is much the same in such nations. And, yet, at least according to libertarian law, she has every right to do so, and is not "obligating" herself to anything at all. 45

Let us now return to Vance. ${ }^{46}$ He starts off with an interesting choice. Libertarians fall into two groups:

- I support Ron Paul even though he is wrong on abortion.

- I don't support Ron Paul because he is wrong on abortion.

I clearly belong in the first camp. Block is in effect my love letter to this magnificent libertarian who is staunchly, and mistakenly, in the pro-life camp. ${ }^{47}$ It is no exaggeration to say that I revere this man, and, yet, respectfully, part company from him on this issue.

Vance then makes a second important bifurcation:

\footnotetext{
44 VANCE, Laurence. Libertarianism and Abortion. Lew Rock Well, [s.I.], July 17 2012. Available at: <http:// archive.lewrockwell.com/vance/vance297.html>.

45 With the exception, of course, of she herself acting in accordance with the NAP. That is her only obligation.

46 VANCE, Laurence. Is Ron Paul Wrong on Abortion? Lew Rock Well, [s.l.], January 29 2008. Available at: <http://archive.lewrockwell.com/vance/vance133.html>.

47 BLOCK, Walter E. Yes to Ron Paul and Liberty. New York: Ishi Press, 2012.
} 
There are two kinds of "pro-choice" libertarians. The first recognizes that abortion is not a settled issue in the libertarian community and therefore hesitates to castigate fellow libertarians who oppose abortion as anti-libertarian or unlibertarian. They are civil, amiable, and likable — like Walter Block...

The second, and more vocal, group of these libertarians is made up of those who are adamant in their belief that opposition to abortion is anti-libertarian or unlibertarian. When a radical, pro-abortion feminist makes a statement like 'fetuses are parasites who derive all their nutrients from the bodies of their hosts, and quite often pose to their hosts serious health complications and risks. Any woman carrying a fetus is being generous,' it doesn't surprise me in the least. But some 'pro-choice' libertarians make statements that are just as outrageous. 48

I greatly regret this, but, I must repay Vance's kindness here with a slight criticism. First, although I readily accept and am grateful for the "civil, amiable, and likable" 49 I am not at all "pro-choice." I am an evictionist - the compromise position between that and pro-life." Second, I am very "adamant"50 that both the pro-choice and the pro- life positions are incompatible with libertarianism.

Vance list several statements of Ron Paul eloquently espousing and defending the pro-life philosophy, including the statement that the "sanctity of life is crucial for the continuation of a civilized society." Vance then asks:

Why would a libertarian have a problem with these statements? Why should it be considered libertarian to kill a baby in the womb or unlibertarian to oppose such killing? And even worse, why would a libertarian say that it was unlibertarian to advocate killing foreigners in an aggressive war but not non-libertarian to kill a baby in the womb?51

Let me attempt to answer this crie de cour. It is unlibertarian to kill innocent foreigners, who never came close to, or even had the power to, attack our country. But, an unwanted "baby in the womb" is a trespasser, harsh as this may sound. The easy case is the infant who is the product of rape. It is hard to deny he is a parasite, albeit a totally innocent one.

\footnotetext{
48 VANCE, Laurence. Is Ron Paul Wrong on Abortion? Lew Rock Well, [s.I.], January 29 2008. Available at: <http://archive.lewrockwell.com/vance/vance133.html>.

49 I regard Vance in exactly the same way

50 Hopefully, in a civil, amiable, and likable manner

51 VANCE, Laurence. Is Ron Paul Wrong on Abortion? Lew Rock Well, [s.I.], January 29 2008. Available at: $<$ http://archive.lewrockwell.com/vance/vance133.html>.
} 
Next, Vance list several comments from libertarians who favor abortion. 52 The gist, here, is that "a fetus is not really a human being" 53 compelling a woman to bear a child against her will amounts to enslaving her ${ }^{54}$ and overriding her right to self-defense. This author invokes the NAP in behalf of forcing the woman to bring the infant to term, even against her will, and emotionally and tellingly cites Murray Rothbard, truly "the twentieth century's greatest proponent of it." Vance neglects to mention that Rothbard is a staunch defender of the pro-choice view. Now, it may well be that "Mr. Libertarian" is inconsistent in these two stances of his. 55 But Vance does not say this.

Let us consider one last point made by Vance. He opines:

Killing someone is the ultimate form of aggression. Especially a helpless, defenseless fetus that is only guilty of suddenly waking up in a womb. The fetus certainly had no control over being a parasite, aggressing against a woman, invading a woman's body, or adding unwanted pounds to his host - but its mother certainly did. If an unborn child is not entitled to protection of life, then to be consistent, libertarians should have no problem with the abortion of a fetus from one month old to nine months old. The nine-month old fetus is no more viable than the one-month old one. 56

I agree, of course, that "the fetus certainly had no control over being a parasite, aggressing against a woman, invading a woman's body." However, it is not true that "its mother certainly did" have this control. Not so, in the case of rape. Nor can I agree that the fetus of one, and nine months, development should be placed in the same category. If both are evicted, not aborted, the former will die, but not the latter. This is a gargantuan difference, one which brings evictionism into sharp focus.

\footnotetext{
52 At: VANCE, Laurence. Is Ron Paul Wrong on Abortion? Lew Rock Well, [s.I.], January 29 2008. Available at: <http://archive.lewrockwell.com/vance/vance133.html>.(Which I adamantly do not)

53 In my view, the fertilized egg is a rights-bearing person.

54 Contrary to the New York Times, I actually oppose slavery. See on this BLOCK, Walter E. Reply to the Scurrilous, Libelous, Venomous, Scandalous New York Times Smear Campaign. Lew Rock Well, [s.I.], January 302014. 55 It is my view that Rothbard is logically consistent in upholding the NAP and taking a pro-choice point of view. I depart from him, only, in thinking that human rights start nine months before birth, not at that time, as does he.

56 VANCE, Laurence. Is Ron Paul Wrong on Abortion? Lew Rock Well, [s.l.], January 29 2008. Available at: <http://archive.lewrockwell.com/vance/vance133.html>.
} 


\section{WATKINS}

The goal of Watkins ${ }^{57}$ is to clarify and defend Thomson 58 . His main contribution is the claim that the latter, for the most part, is filled not with analogies to abortion, but, rather, with counter-examples. To a degree, then, his essay is somewhat oblique or peripheral to the main concerns of the present paper, which is to view all libertarian discussions of abortion with regard to how they square with evictionism. Watkins' essay does not confront this question explicitly, although he does touch upon it implicitly.

Another difficulty with Watkins from this perspective is that he is focused, as is Thomson, on morality, immorality, decency and other such concepts.59 If he would define any of them, he and I could at least have more of a chance of achieving real disagreement 60 . In the event, he does not, ${ }^{61}$ which makes this goal less attainable. But, we shall press on in any case.

Its main drawback from the viewpoint of the present paper is that it does not directly confront the evictionist hypothesis. The closest it comes to addressing this point of view is when it mentions "disconnect"62. But, it is only the forced kidney donor disconnecting himself from the violinist that is discussed, not the mother from the fetus. Watkins, also, in this regard distinguishes between allowing to die and killing, but denigrates this distinction:

But does anyone think that it would be morally better to surgically remove a nonviable fetus without killing it, knowing that it cannot survive outside the womb? So the

\footnotetext{
57 WATKINS, Michael. Re-reading Thomson:Thomson's unanswered challenge. Journal of Libertarian Studies, Auburn, vol. 20, n. 4, p. 41-59, sept./dec. 2006.

58 THOMSON, Judith Jarvis. A Defense of Abortion. Philosophy \& Public Affairs, New Jersey, vol. 1, n. 1, p. 69-80, sept./dec. 1971.

59 WATKINS, Michael. Re-reading Thomson:Thomson's unanswered challenge. Journal of Libertarian Studies, Auburn, vol. 20, n. 4, p. 41-59, sept./dec. 2006.

60 This author uses the phrase "morally indecent" some half dozen times, without ever once indicating what he means by it; Watkins gives his readers no independent criterion of its definition.

61 Nor does Thomson. See on this Block, unpublished. Matters are even worse, in the sense that subjectivism of language rears its ugly head. What are we to make of the claim of Watkins'"Most of us have the intuition that..." This may well be true, but it hardly constitutes justification for any belief. He continues:"... that it is permissible to kill someone, even an innocent someone, in self-defense, and not merely when our lives are at risk, but also where what is at risk is serious physical or psychological harm."WATKINS, Michael. Re-reading Thomson: Thomson's unanswered challenge. Journal of Libertarian Studies, Auburn, vol. 20, n. 4, p. 41-59, sept./dec. 2006. p. 45. For a very different perspective on this issue, one not based on "intuition" but rather on logical implications of the NAP, see BLOCK, Walter E. Response to Jakobsson on human body shields. Libertarian Papers, 2010. Available at: <http://libertarianpapers.org/2010/25-block-response-to-jakobsson-on-human-body-shields/ $>$. 62 WATKINS, Michael. Re-reading Thomson: Thomson's unanswered challenge. Journal of Libertarian Studies, Auburn, vol. 20, n. 4, p. 41-59, sept./dec. 2006. p. 44-45.
} 
active-passive distinction, whatever moral weight it might have in some cases, would seem to be irrelevant for morally evaluating cases of abortion. 63

Well, yes. This distinction does not amount to too much, given present medical technology, for the first two trimesters. But what about the third trimester? Here, this distinction is absolutely crucial; it spells the difference between abortion and eviction. But this author is too focused on "morality" to even consider this. Partial birth abortion in the seventh through ninth months is out and out murder, given that a "separation" or a "disconnect" between mother and (premature) baby is an alternative. This is an option completely ignored by this author.

Next, consider Watkins treatment of Thomson's example where "you are stuck in a very small house with a rapidly growing child that will crush you if you don't kill it." Watkins continues: "Surely it is not murder to kill the child to save your life." 64 Not so fast. At least for the libertarian 65 it all depends upon who is the owner of the house. If it is the child, then it most certainly is murder "to kill the child to save your life." It is his house, after all. What in bloody blue blazes are you doing in his house, ready to murder him, when he has every right to expand as much as he wants. It is his house, after all. In actual point of fact, getting back to reality if just for one brief moment, who's "house" is it that we are talking about when we discuss evictionism? Why, of course, the womb is the mother's house. Therefore, she has a right to remove inhabitants of these premises of hers she does not, or no longer, welcomes. They then become trespassers. The unwilling host of the violinist has a right to separate herself from him; to disconnect from him; to secede from him, dislodge him, if you will. But, being an innocent trespasser, he lacks mens rea, she has no right to slit his throat or shoot him. She is obligated, at least on the basis of libertarian law, to detach herself from him in the gentlest manner possible.

Watkins avers that Thomson's "point is that it has not been shown that rights are in conflict whenever a woman contemplates whether to have an abortion, even if we assume that the fetus has a right to life." Before responding substantively to this fallacy, first allow me to translate this into language acceptable to a libertarian: I substitute "right not to be murdered" a negative right, for "right to life" which is a positive one. ${ }^{66}$ Since every right implies an obligation, the former, correct, version of this mandates that no one shall commit murder, while the latter incorrect one translates into

63 WATKINS, Michael. Re-reading Thomson:Thomson's unanswered challenge. Journal of Libertarian Studies, Auburn, vol. 20, n. 4, p. 41-59, sept./dec. 2006. p. 45.

64 WATKINS, Michael. Re-reading Thomson:Thomson's unanswered challenge. Journal of Libertarian Studies, Auburn, vol. 20, n. 4, p. 41-59, sept./dec. 2006. p. 46.

65 This author also publishes in the Journal of Libertarian Studies. Does this give us the "right" to expect that libertarian considerations would play a role in his analysis?

66 WATKINS, Michael. Re-reading Thomson:Thomson's unanswered challenge. Journal of Libertarian Studies, Auburn, vol. 20, n. 4, p. 41-59, sept./dec. 2006. p. 48. 
the requirement that we must keep such a person alive. We thus arrive at the following: Thomson's "point is that it has not been shown that rights are in conflict whenever a woman contemplates whether to have an abortion, even if we assume that the fetus has a right ... (not to be murdered)." As such, this is false. For there most certainly is a clash in rights when a woman decides to have an abortion. This act involves not one thing, but two: eviction, separation, secession, disconnection, on the one hand, and, on the other, outright murder. Why oh why cannot the woman, and Watkins and Thomson along with her, be satisfied with removing the fetus from her "house," but not actively killing it? There is no more important distinction in this entire controversy, Watkins view that it is "irrelevant" to the contrary notwithstanding. ${ }^{67}$

Next, Watkins maintains "... no sound argument against abortion has yet to be provided even after we grant that a fetus is a person." He continues: "... how hard it is to find a general principle that is both obviously true and that applies to a wide range of abortion cases." I cannot see my way clear to accepting either of these charges. Au contraire, it is easy to find a "general principle ... against abortion" based on the assumption, which I fully and enthusiastically accept, that the fetus is a rights-bearing person, like all other human beings. It is simple. The principle is the NAP, and private property rights. The mother owns the premises under contention. It is her womb, no one else's. Therefore she and she alone has the right to determine who or what shall inhabit her property, her "house." 68 But she only has the right to evict, or depart from or separate from or secede from, any unwanted visitor; not to murder him. Evictionism solves this dispute. Abortion, which is eviction plus murder, most certainly does not.

States Watkins: "No general argument against abortion will prove successful." 69 Too bad, for him, he never so much has even considered evictionism. He repeats this sentiment: "... no general argument ... will ever successfully show that abortion is immoral in a board range of cases."70 I do not know about morality, since he has not vouchsafed us to define this concept, but abortion, in the third trimester, most certainly is an example of murder, and one third of fetuses, at any given time, are in the seventh, eighth or ninth months of their gestation, and is this is not a "broad range of cases" then nothing is.

67 WATKINS, Michael. Re-reading Thomson:Thomson's unanswered challenge. Journal of Libertarian Studies, Auburn, vol. 20, n. 4, p. 41-59, sept./dec. 2006. p. 45.

68 WATKINS, Michael. Re-reading Thomson:Thomson's unanswered challenge. Journal of Libertarian Studies, Auburn, vol. 20, n. 4, p. 41-59, sept./dec. 2006. p. 52.

69 WATKINS, Michael. Re-reading Thomson:Thomson's unanswered challenge. Journal of Libertarian Studies, Auburn, vol. 20, n. 4, p. 41-59, sept./dec. 2006. p. 42.

70 WATKINS, Michael. Re-reading Thomson:Thomson's unanswered challenge. Journal of Libertarian Studies, Auburn, vol. 20, n. 4, p. 41-59, sept./dec. 2006. p. 57. 


\section{CONCLUSION}

It is one thing that the general populace does not embrace evictionism. Its intellectuals 71 do not start from the same premises as do libertarians: the NAP coupled with private property rights. Thus, we cannot in good conscience expect widespread agreement with this viewpoint. It is entirely a different matter within the libertarian community. Here, we all do accept these basic starting points. So, it is rather more disappointing that its spokesmen do not come to the same conclusion. The present paper is an attempt to rectify the analyses of several prominent libertarians who really should know better. Hopefully, it will convince not only them, but many others. The fate of many, many babies rests in the balance.

\section{REFERENCES}

ANDERSSON, Anna-Karin. An alleged contradiction in Nozick's entitlement theory. Journal of Libertarian Studies, Auburn, vol. 21, n. 3, p. 43-63, mar./june 2007.

BARNETT, Randy E. Contract Remedies and Inalienable Rights. Social Philosophy \& Policy, Cambridge, vol. 4, issue 1, p. 179-202, sept./dec. 1986.

BARNETT, Randy E. The Structure of Liberty: Justice and the Rule of Law, Oxford: Clarendon Press, 1988.

BLOCK, Walter. Voluntary Slavery. The Libertarian Connection, [s.I.], vol. I, n. 3, p. 9-11, apr. 1969. BLOCK, Walter E. Toward a Libertarian Theory of Abortion. The Libertarian Forum, Auburn, vol. 10, n. 9, p. 6-8, sept. 1977.

BLOCK, Walter E. Book review of Nancy C. Baker, Baby Selling: the Scandal of Black Market Adoptions, New York: The Vanguard Press, 1978. Libertarian Review, San Francisco, vol. 7, n. 12, p. 44-45, jan. 1979.

BLOCK, Walter E. Market Inalienability Once Again: Reply to Radin. Thomas Jefferson Law Journal, San Diego, vol. 22, n. 1, p. 37-88, mar./june 1999.

BLOCK, Walter E. Alienability, Inalienability, Paternalism and the Law: Reply to Kronman. American Journal of Criminal Law, Austi, vol. 28, n. 3, p. 351-371, june/sept. 2001.

BLOCK, Walter E. Toward a Libertarian Theory of Inalienability: A Critique of Rothbard, Barnett, Gordon, Smith, Kinsella and Epstein. Journal of Libertarian Studies, Auburn, vol.17, n. 2, p. 3985, mar./june 2003.

71 Boonin, (BOONIN-VAIL, David. A Defense of 'A Defense of Abortion': On the Responsibility Objection to Thomson's Argument. Ethics, [s.I.], vol. 107, n. 2, p. 286-313, jan. 1997; BOONIN-VAIL, David. A defense of abortion. Cambridge: Cambridge University Press, 2002) is a case in point. 
BLOCK, Walter E. Ayn Rand and Austrian Economics: Two Peas in a Pod. The Journal of Ayn Rand Studies, University Park (PA), vol. 6, n. 2, p. 259-269, mar./june 2005.

BLOCK, Walter E. Epstein on alienation: a rejoinder. International Journal of Social Economics, [s.l.], vol. 33, n. 3-4, p. 241-260, 2006.

BLOCK, Walter E. Alienability: Reply to Kuflik. Humanomics, [s.I.], vol. 23, n. 3, p. 117-136, 2007.

BLOCK, Walter E. Yes, Sell Rivers! And Make Legal Some Slave Contracts. The Tyee,, Victoria, Opinion, July 25 2009. Available at: <http://thetyee.ca/Opinion/2009/07/24/SellRivers/>.

BLOCK, Walter E. Privatizing Rivers and Voluntary Slave Contracts. Lew Rock Well, [s.l.], July 27 2009, Available at: <http://www.lewrockwell.com/block/block134.html>.

BLOCK, Walter E. Response to Jakobsson on human body shields. Libertarian Papers, 2010. Available at: <http://libertarianpapers.org/2010/25-block-response-to-jakobsson-on-human-body-shields/>.

BLOCK, Walter E. Yes to Ron Paul and Liberty. New York: Ishi Press, 2012.

BLOCK, Walter E. Reply to the Scurrilous, Libelous, Venomous, Scandalous New York Times Smear Campaign. Lew Rock Well, [s.I.], January 302014.

BLOCK, Walter E. Judith Jarvis Thomson on abortion; a libertarian perspective. Unpublished.

BLOCK, Walter E. Response to Feser on libertarianism. Journal Etica e Politica/Ethics \& Politics, Trieste. Forthcoming.

BLOCK, Walter E.; WHITEHEAD, Roy. Compromising the Uncompromisable: A Private Property Rights Approach to Resolving the Abortion Controversy. Appalachian Journal of Law, Grundy, vol. 4, n. 1, 2005.

BOONIN-VAIL, David. A Defense of 'A Defense of Abortion': On the Responsibility Objection to Thomson's Argument. Ethics, [s.l.], vol. 107, n. 2, p. 286-313, jan. 1997.

BOONIN-VAIL, David. A defense of abortion. Cambridge: Cambridge University Press, 2002.

CALABRESI, Guido; MELAMED, Douglas. Property Rules, Liability Rules, and Inalienability: One View of the Cathedral. Harvard Law Review, Cambridge, vol. 85, n. 6, p. 1089-1128, apr. 1972.

EPSTEIN, Richard. Why Restrain Alienation. Columbia Law Review, New York, vol. 85, p. 971-990, 1985.

EVERS, Williamson. Toward a Reformulation of the Law of Contracts. Journal of Libertarian Studies, Auburn, vol. 1, p. 3-13, jan./mar. 1977.

FESER, Edward. Self-ownership, abortion, and the rights of children: toward a more conservative libertarianism. . Journal of Libertarian Studies, Auburn, vol. 18, n. 3, p. 91-114, june/sept. 2004. 
FREDERICK, Danny. Voluntary Slavery. Las Torres de Lucca, Madrid, vol. 3, n. 4, p. 115-137, ene./ jun. 2014.

KERSHNAR, Stephen. A Liberal Argument for Slavery. Journal of Social Philosophy, [s.l.], vol. 34, n. 4, p. 510-536, 2003.

GORDON, David. Private Property's Philosopher. The Mises Review, Auburn, vol. 5, n. 1, p. 1-7, mar./june 1999.

KINSELLA, N. Stephan. Inalienability and Punishment: A Reply to George Smith. Journal of Libertarian Studies, Auburn, vol. 14, n. 1, p. 79-93, dec./mar. 1998-99.

KINSELLA, N. Stephan. A Libertarian Theory of Contract: Title Transfer, Binding Promises, and Inalienability. Journal of Libertarian Studies, Auburn, vol. 17, n. 2, p. 11-37, mar./june 2003.

KRONMAN, Anthony. Paternalism and the Law of Contracts. 92 Yale Law Journal, New Haven, vol. 92, 1983.

KUFLIK, Arthur. The Inalienability of Autonomy. Philosophy and Public Affairs, New Jersey, vol. 13, n. 4, p. 271-298, mar./june 1984.

KUFLIK, Arthur. The Utilitarian Logic of Inalienable Rights. Ethics, [s.I.], vol. 97, p. 75-87, oct. 1986.

LESTER, Jan Clifford. Escape from Leviathan. New York: St. Martin's Press, 2000.

MACK, Eric. The Self-Ownership Proviso: A New and Improved Lockean Proviso. Social Philosophy and Policy, Cambridge, vol. 12, n. 1, jan./mar. 1995.

MCCONNELL, Terrance. The Nature and Basis of Inalienable Rights. Law and Philosophy, [s.I.], vol. 3, n. 1, p. 25-59, 1984.

MCCONNELL, Terrance. The Inalienable Right of Conscience: A Madisonian Argument. Social Theory \& Practice, [s.l.], vol. 22, issue 3, p. 397-416, mar./june 1996.

MOSQUITO, Bionic. Walter Block, Specific Performance Contracts, and Abortion. July 122015. Available at: <http://bionicmosquito.blogspot.com/2015/07/walter-block-specific-performance. html>.

MOSQUITO, Bionic. The Sanctity of Contract. April 19 2014. Available at: <http://bionicmosquito. blogspot.com/2014/04/the-sanctity-of-contract.html>.

NOZICK, Robert. Anarchy, State and Utopia. New York: Basic Books, 1974.

RADIN, Margaret Jane. Time, Possession and Alienation. Washington University Law Quarterly, Washington, vol. 64, n. 3, p.739-758, 1986.

RADIN, Margaret Jane. Market-Inalienability. Harvard Law Review, Cambridge, vol. 100, n. 8, p. 1849-1937, june 1987.

REISMAN, George. Capitalism. Ottawa: Jameson Books, 1996. 
RICHMAN, Sheldon. Slaves contracts and the inalienable will. The Libertarian Forum, Auburn, p. 4-5, jul./aug., 1978. Available at: <http://mises.org/journals/lf/1978/1978_07-08.pdf>.

ROTHBARD, Murray N. For a New Liberty: The Libertarian Manifesto. Auburn: Ludwig von Mises Institute, 1973.

ROTHBARD, Murray N. The editor replies. The Libertarian Forum, Auburn, p. 3, jul./aug. 1978. Available at: <http://mises.org/journals/lf/1978/1978_07-08.pdf>.

ROTHBARD, Murray N. The Ethics of Liberty. Atlantic Highlands: Humanities Press, 1998.

SADOWSKY, James. 1978. Abortion and Rights of the Child. The Libertarian Forum, Auburn. p. 2-3, jul./aug. 1978. Available at: <http://mises.org/journals/lf/1978/1978_07-08.pdf>.

SMITH, George. A Killer's Right to Life. Liberty, [s.I.], vol. 10, n. 2, p. 46-54, nov. 1996.

SMITH, George. Inalienable Rights? Liberty, [s.I.], vol. 10, n. 6, p. 51-?, jul. 1997.

STEINER, Hillel. An Essay on Rights. Oxford: Blackwell Publishers, 1994.

THOMSON, Judith Jarvis. A Defense of Abortion. Philosophy \& Public Affairs, New Jersey, vol. 1, n. 1, p. 69-80, sept./dec. 1971.

THOMSON, Judith Jarvis. The Realm of Rights. Cambridge: Harvard University Press, 1990.

VANCE, Laurence. Is Ron Paul Wrong on Abortion? Lew Rock Well, [s.I.], January 29 2008. Available at: <http://archive.lewrockwell.com/vance/vance133.html $>$.

VANCE, Laurence. Libertarianism and Abortion. Lew Rock Well, [s.l.], July 17 2012. Available at: $<$ http://archive.lewrockwell.com/vance/vance297.html>.

WATKINS, Michael. Re-reading Thomson: Thomson's unanswered challenge. Journal of Libertarian Studies, Auburn, vol. 20, n. 4, p. 41-59, sept./dec. 2006. 